\title{
The Amherst embassy and British discoveries in China
}

\begin{abstract}
The Amherst embassy to China has long been viewed as a major diplomatic failure in Britain's early relations with China. This article concentrates on the greatly overlooked aspect of the Amherst mission - the delegation's discoveries in China after the official proceedings were concluded. Since the embassy was given unprecedented freedom of movement during its four-month return journey from Beijing to Canton, British observers were able to explore the interior of China and to communicate more fully with the Chinese government and people than ever before. As a consequence, the Amherst embassy not only provided valuable first-hand observations which increased and improved Britain's knowledge of China, but developed the view that the Qing government was the chief obstacle to the progress of Chinese civilization and to the general welfare of the Chinese people. These important perceptions laid the foundation for future changes in Sino-British relations and led, indirectly, to the outbreak of the Opium War.
\end{abstract}

The Amherst embassy to China (1816-17) is a largely under-researched, but very critical, event in the progress of British-Chinese relations. It was dispatched twenty-two years after the unsuccessful Macartney embassy (1792-4), the inaugural British mission to China, and was the British government's second attempt to improve the country's commercial and diplomatic relations with the Chinese empire. Compared to Macartney's embassy, which was at least given the opportunity to meet the Qianlong emperor, the Amherst mission has long been regarded as less productive, primarily because it did not even achieve an audience with the Jiaqing emperor. Largely for this reason, unlike Macartney's mission, the Amherst embassy has attracted very little scholarly attention. No major secondary source deals specifically with this incident and most studies which have mentioned it are rather brief and are largely descriptive. ${ }^{1}$ This neglect of the Amherst embassy, moreover, is partly because the official proceedings of this mission lasted only about twenty days, a fact has led one historian to remark that 'except for creating ill feeling on both sides, nothing was achieved'. ${ }^{2}$ Although, as in the case of the Macartney embassy, Amherst's refusal to kowtow to the Chinese emperor has been studied, ${ }^{3}$ the importance of the British travellers' discoveries during the rest 
of their stay in China, especially during their four-month return journey through the interior of the Chinese empire, has been very largely overlooked. This failure to investigate the various views of China developed and published by several members of the Amherst embassy, has left much valuable information on Britain's early perceptions of China unexplored. Only by investigating what information and attitudes were disseminated to the British public by these members of the Amherst embassy is it possible to understand how Britain perceived the Chinese government and its relations with it on the eve of the fateful Opium War of the 1840s.

From the early seventeenth to the second half of the eighteenth century, Catholic missionaries in China and some key enlightenment philosophers, such as Leibniz and Voltaire, aroused widespread enthusiasm for Chinese civilization in Europe. ${ }^{4}$ Partly as a consequence, Britain developed an admiration for China, which reached its pinnacle in the late seventeenth century. ${ }^{5}$ Although, during the course of the eighteenth century, the balance between favourable and unfavourable views of China in Britain was shifting away from the former and towards the latter, ${ }^{6}$ this change of attitude was largely owing to the changing values of British society, ${ }^{7}$ rather than British people's direct discoveries about the Chinese empire. Apart from Commodore George Anson's Voyage Round the World (1748), ${ }^{8}$ for most of the eighteenth century, Britain could benefit from very few first-hand accounts of China written by British travellers to that country. The real situation of the Chinese empire hence remained by and large mysterious. In this context, the Macartney embassy provided the very first opportunity for some Britons to traverse the interior of China and to observe the country more closely than ever before. Although this first embassy failed to achieve its commercial and diplomatic objectives, these British travellers were able to bring home some first-hand 
observations on the current state of the Chinese empire. Most notably, after examining various aspects of Chinese society, both Macartney and his deputy, George Leonard Staunton, were convinced that, despite the high degree of perfection which the Chinese had achieved in the past, they had failed to progress and had even taken some retrograde steps in recent times. ${ }^{9}$ This belief in China's backwardness particularly appealed to Britain's elite class at the beginning of the nineteenth century, but until the launch of the Amherst embassy in 1816, a general consensus on the state of Chinese civilization had not yet been reached in Britain.

This failure to achieve an agreed image of China terminated, however, after the Amherst embassy. In comparison with the Macartney mission, members of the Amherst embassy were provided with much greater opportunities to explore the real state of Chinese society. During the return journey from Beijing to Canton [Guangzhou], in particular, the experience of Amherst's mission differed markedly from that of the previous embassy. The Macartney embassy's freedom of movement had been strictly constrained by the government of the Qianlong emperor. In Macartney's own words, throughout the embassy's residence in China, 'we have indeed been very narrowly watched, and all our customs, habits and proceedings, even of the most trivial nature, observed with an inquisitiveness and jealousy which surpassed all that we had read of in the history of China'. ${ }^{10}$ During the embassy's return journey, particular care was taken by the Chinese authorities to prevent the British from making contact with the common people of China. When the British requested permission to make some excursions from their boats into the nearby towns or countryside, 'our wishes were seldom gratified'. ${ }^{11}$ In sharp contrast, the Amherst embassy was not subject to the same restrictions during most of its stay in China. After its members were compelled to leave Beijing, the Amherst mission quite unexpectedly enjoyed 'a greater degree of liberty than had been granted to any former embassy'. ${ }^{12}$ During their prolonged return journey across mainland China, members of the Amherst mission were not only allowed to wander about 
various Chinese cities, towns and rural areas, but were also able to have contact with different ranks of Chinese people, including artisans, merchants and others in the middle and lower ranks of Chinese society. This unprecedented liberty of movement enabled these travellers to observe the Chinese empire more closely than any previous British visitors. In consequence, Britain's limited first-hand knowledge on China was greatly expanded, when members of the embassy reported on their experiences after their return to Britain.

Moreover, the Amherst embassy's return journey covered new areas and lasted a longer time. Unlike the Macartney mission which travelled to the southern end of the Grand Canal, the Amherst embassy transferred from Guazhou to the renowned Yangtze River. Its members then sailed 285 miles along the Yangtze to join the Poyang Lake, from whence the embassy travelled on smaller inland waterways to Canton. The Jiaqing emperor ordered the British to be conducted along this route, because it was believed to be the quickest route from Beijing to Canton. Nevertheless, due to adverse weather conditions, the journey took considerably longer than expected. It resulted in 'the fortunate occasion' ${ }^{13}$ which allowed members of the Amherst embassy not only to spend more time in the interior of China, but also to visit some parts of the lower Yangtze delta, the most prosperous region of the Chinese empire that had hitherto not been explored by any Europeans.

As a consequence of the opportunities afforded by this journey to these British visitors, the first-hand evidence about the country and the people of China gained by the Amherst embassy was far greater than that gained by members of Macartney's embassy. Eleven members of the Amherst mission left more than fifteen accounts of their visit to China. Although Amherst's diary was lost because of the shipwreck of the embassy's main ship on its return voyage, some of Amherst's observations on China can still be found in the India Office Library and Records held in the British Library. George Thomas Staunton, Macartney's page on the first mission and the son of George Leonard Staunton, served as the 
second commissioner of the Amherst embassy. As an eminent 'China expert', Staunton subsequently produced several works that relate to the Amherst mission. ${ }^{14}$ Henry Ellis, the third commissioner, published his Journal of the Proceedings of the Late Embassy to China shortly after he returned to Britain. ${ }^{15}$ This book was widely considered to be the most official account of the Amherst mission. Robert Morrison, who had entered China in 1807 as the pioneer Protestant missionary, was the chief translator for Amherst's embassy. With his remarkable knowledge of the Chinese culture and language, Morrison was able to publish $A$ View of China $^{16}$ as well as his memoir of the Amherst mission. ${ }^{17}$ After Morrison died, his wife compiled the two-volume Memoirs of the Life and Labours of Robert Morrison, D.D., which complements Morrison's observations on China published in his earlier works. ${ }^{18}$ John Francis Davis, who also had a good command of the Chinese language, ${ }^{19}$ authored a number of books on China and its people, such as Sketches of China which includes his journal of the embassy. Apart from these individuals, other members of the Amherst mission who kept or published journals of their visit to China include: Clarke Abel, the chief medical officer and naturalist; John Macleod, a surgeon aboard the Alceste; Basil Hall, the commander of HMS Lyra; and Henry Hayne, Amherst's private secretary. ${ }^{20}$

Despite the relative abundance of available primary sources, it should be noted that, under the influence of Edward Said's Orientalism, an increasing number of historians have been aware of the patronizing attitudes which westerners often adopted towards oriental societies during their encounters with the latter. ${ }^{21}$ Elizabeth Hope Chang, for example, has stated in her recent book that, instead of showing China as it really was, the vision of China in nineteenth-century Europe was 'in fact a reflection mirrored back to the European reader by a representation made by a Western writer'. ${ }^{22}$ Such views are unquestionably useful correctives for our previous understanding of early western attitudes towards China, but, in the case of the Amherst embassy, it would be equally erroneous to ignore the worsening state 
of the Qing dynasty after Macartney's embassy. When Macartney was visiting the Qing court, China was at the very end of the so-called 'Kang-Qian shengshi (prosperous age of the Kangxi until the Qianlong reigns, 1662-1795)'. Even though Macartney described China as 'an old, crazy, first-rate Man of War' ${ }^{23}$ he was in fact comparing the Chinese empire with a glorious past that was the product of many westerners' imagination. When Amherst reached China in the later 1810s, however, signs of Qing's dynastic decline had become increasingly evident. Overpopulation, land shortage and unceasing rebellions were major developments during this period. ${ }^{24}$ The imperial government, moreover, was facing serious fiscal problems, which obliged the Jiaqing emperor to give up the extravagant tradition of southern tours along the Grand Canal to the lower Yangtze delta. Since the numerous lavishly decorated buildings on this route, many of which had been built expressly for these imperial tours, remained unattended after the Qianglong emperor's last visit in 1784, their dilapidation, when they were seen by members of Amherst's embassy, became a clear and visible indicator of China's decline under the present emperor. On the basis of this discovery, the widelycirculated image in Britain of a backward and declining Chinese empire could be supported for the first time by an abundance of reliable first-hand evidence. This considerable increase in Britain's knowledge on China not only led to a deterioration in British opinions of China, but helped change Sino-British relations in the pre-Opium War era.

\section{II}

In the various accounts of China produced by members of the Amherst embassy, there was a general impression that China was in decay during the reign of Jiaqing. Staunton, as the only person who had travelled with both embassies, maintained that, 'there can be little doubt that the prosperity of this empire has been on the decline under the government of the present emperor, that is, since the period at which it was visited by Lord Macartney's embassy'. ${ }^{25}$ 
Staunton wrote that 'in most points, our present views and estimation of the country and inhabitants, seem to differ from those which were formed by the former party, for the worse ${ }^{26}$ and he believed that it could be attributed to 'the different state of the imperial finances at the two periods'. ${ }^{27}$ Having read in the Peking Gazette [Jing Bao] that the Jiaqing emperor was compelled to abandon even the refurbishment of his own garden for want of available funds, ${ }^{28}$ Staunton became convinced that the Chinese empire was indeed declining under its present ruler. To prove this, Staunton recorded every sign of poverty and dilapidation that he discovered throughout the long journey from Beijing. As a result, terms such as 'decay', 'decline', and 'ruinous' can be frequently found in his journal. Staunton even claimed that 'almost every public building we have seen in our route, has exhibited to us more or less evidence of the poverty or negligence of the government' ${ }^{29}$ In order to illustrate the destitution common in the Chinese countryside, Staunton wrote:

These hills are perfectly barren, and destitute even of trees - no signs whatever of cultivation or inhabitants, except at their feet near the river, or in the lowest parts of the intervening vallies. At one, we passed on our left a ruined pagoda of nine stories - It seemed wholly abandoned, and had no house or religious establishment of any kind in its vicinity. ... Some spots had very much the appearance of the entrance of mines which, being no longer worked, had been neglected, and closed up. ${ }^{30}$

With regard to an average city in Jiangxi Province, he recorded that:

Within the walls we found no improvement in the style of the houses, or any shops that attracted our attention - the walls were low and ruinous ... a range of buildings ... in the style of a large joss-house, but at present in a ruinous state, and wholly untenanted ... the tribunals of the Nan-gan-foo or governor, ... it is certainly at present the poorest and most ruinous ... The governor's tribunal and residence, was a lofty and extensive, but neglected pile of building. The tribunal of the Hien ... appeared in so ruinous a state as to be scarcely habitable ... several stone pailoos ... seemed to denote that this city had once existed in a state of comparative splendor, from which it had latterly declined. ${ }^{31}$ 
Other members of the embassy joined with Staunton in providing their readers with an image of a declining China, even though they had not visited China two decades before. Henry Ellis, when passing Tsing-heen [Qing xian], noted that 'the walls and the town itself are falling to decay'. ${ }^{32}$ In viewing a pagoda near the city of Nanchang, Ellis commented that it was 'in exceedingly bad proportions' and 'evinced the decay of architecture among the Chinese'. ${ }^{33}$ John Davis, subsequent to his visit to Wu-yuan, an imperial residence of the Qianlong emperor, could not conceal his disappointment at what he saw. He entered into his Sketches of China that, 'Like almost everything of the kind that we had seen in the country, this once decorated abode was in a sad state of dilapidation and ruin and calculated to produce no other emotions than those of melancholy,. ${ }^{34}$ After Clarke Able paid a visit to the celebrated city of Guazhou, similar scenes were recorded in his narrative. He wrote that:

The city of Qua-tchow [Guazhou] did not answer the expectations raised by its advantageous situation. Its streets exhibited no characters of opulence, and its walls were in ruins. In the days of Kien-Lung [Qianlong], it flourished under imperial favour; ... Since these golden days in the history of Qua-tchow, as its governor informed Mr Morrison, the Fung-shway [Feng-shui], or "fortune of the place," had gradually declined. ${ }^{35}$

Based on their conviction that China was in decay, these British travellers became increasingly disenchanted with the state of Chinese civilization. Although, at the beginning of the Amherst mission, members of the embassy was still divided into 'those who landed with an impression that the Chinese were to be classed with the civilized nations of Europe' and others who 'ranged them with the other nations of Asia', ${ }^{36}$ by the end of the mission, a general consensus on the backwardness of China had emerged. This unfavourable perception of the Chinese empire was based, first of all, on the perceived image of the Chinese being an unrefined people. Upon their arrival on the China coast, members of the Amherst embassy were soon 'astonished to find the fishermen in their boats as naked as savages, without 
appearing conscious of shame. Sometimes they wore a jacket over their shoulders, but had no clothing for the lower part of the body'. ${ }^{37}$ It was also a commonly-held view that 'poor boys to the age of twelve or thirteen were generally naked, standing, running about in promiscuous crowds'. ${ }^{38}$ In light of these impressions, the Chinese were more and more presented to readers of these accounts as a barbaric people, who were frequently compared with animals rather than with other human beings. For instance, when Basil Hall gave the local shipmen some dollars as presents, he noted that 'The captain and his crew assembled in a ring, and turned over the pieces from hand to hand, just as I have seen a group of monkeys do when puzzled with some new object'. ${ }^{39}$ The residences of ordinary Chinese people, in Abel's opinion, were 'miserable beyond anything which England can exemplify' and 'more like the dens of beasts than the habitations of men' ${ }^{40}$

In light of these discoveries, 'dirt, squalidness, and extreme poverty' were identified as the 'leading characteristics' of ordinary Chinese people. ${ }^{41}$ Their unhygienic living conditions were particularly highlighted by these British observers. Abel found that, in addition to the shortage of clean water and the ubiquity of mosquitoes in many parts of China, ${ }^{42}$ 'The Chinese are less fastidious than perhaps any other people in the choice of their food' ${ }^{43}$ Whenever dead pigs or rotting vegetables were thrown overboard from the British ships, there were always some Chinese people rushing to pick them up and eat them afterwards. The Chinese, moreover, were believed to be a people 'utterly insensible to bad smells' ${ }^{44}$ When surrounded by curious crowds in Tianjin, Ellis recalled that, 'there literally prevails a compound of villainous stenches, and this constitutes one of the principal inconveniences of the crowd that gather round us'. ${ }^{45}$ On a visit to the famous 'Bath of Fragrant Water' near Nanjing, the empire's second city, Ellis claimed that 'the stench is excessive; altogether I thought it the most disgusting cleansing apparatus I had ever seen and worthy of this nasty nation'. ${ }^{46}$ On the same occasion, Abel noted that, 'There appeared no intention of renewing 
the water [which] thus become saturated with dirt ... The steam arising from it, however fragrant to the senses of the Chinese, was to mine really intolerable, and drove me away before I could ascertain in what manner the baths were heated'. ${ }^{47}$ By such multi-sensory examinations, the Chinese people's want of cleanliness, as well as the general image of them as an unrefined people, was further confirmed.

The British travellers' disenchantment with Chinese civilization was intensified by the poor condition of the public infrastructure in China. According to the accounts provided by the members of Amherst's embassy, the majority of the streets in Chinese cities were 'imperfectly paved, narrow, and saturated with bad smells' ${ }^{48}$ The roads Amherst took in Tongzhou, for example, were so 'dirty and slippery' that 'the poor creatures who carried the chairs were up to the knees in water'. ${ }^{49}$ The express way, which the Chinese promised to be of superior construction, turned out to be simply 'a broad road of hewn granite, which was evidently very old, and in so ruined a state that it might have been referred to [in] the days of Yaou and Shun'. ${ }^{50}$ Even the Grand Canal, which was renowned 'as an example of the immense power of human labour and human art', ${ }^{51}$ proved to be much overrated, because most of it was 'only a natural river, modified and regulated by sluices and embankments' ${ }^{52}$ In a similar way, the vehicles which the Qing government provided for the use of Amherst's embassy were also found to be extremely uncomfortable. The Chinese boats were said to be 'ill constructed for comfort in cold weather' ${ }^{33}$ and the junks for conveying supplies 'the most clumsy looking vessels imaginable' ${ }^{54}$ The Chinese carts were also deemed to be 'the most execrable machines imaginable'. ${ }^{55}$ Riding in these carriages, Morrison noted that, 'without constant effort to hold by the sides of the carriage, a person's head was thrown first on one side and then on the other'. ${ }^{56}$ During an exhausting overnight journey from Tongzhou to Beijing, Davis expressed his regret at having exchanged his horse for one of these 'wretched little Chinese tilted carts', because 'the convulsive throes of this primitive machine, without 
springs, on the ruined granite road, produced an effect little short of lingering death; and the only remedy was to get out as often as possible and walk' ${ }^{57}$ By contrast, Robert Morrison observed that it was probably due to the poor transport available in China that Amherst's British-made carriage attracted so much admiration from the Chinese and was widely recognized by them as 'proper for the Emperor'. ${ }^{58}$

In addition to such observations on the facilities and infrastructure in China, the British visitors commented on the state of the Chinese military. Many military posts in China, as with other public buildings, were considered to be in urgent need of repair. In particular, the British observers found it amusing and absurd that some watch-towers in Shandong province, formed entirely of mats, were painted to imitate brick or stone. This was regarded by Davis as 'a most unequivocal proof of the unwarlike habits of the nation'. ${ }^{59}$ Members of Amherst's embassy also concluded that 'the art of war must be in a very low state' ${ }^{60}$ in China. Through contacts with various Chinese soldiers and mandarins, the British travellers found that bodily strength and courage were still seen by the Chinese as the only qualities that were required for military advancement. Bows and arrows, indeed, were the most frequently used weapons of Chinese military men. Most of the matchlocks that the British saw in China were 'truly wretched and appeared rusted through, so as not to be fired without danger'. ${ }^{61}$ When Chinese soldiers, most of whom were 'of a very poor and inefficient description', ${ }^{62}$ were using these weapons, 'they immediately retreat upon applying the match, squatting down at a short distance with their backs turned; the iron tube is always placed upright, so that every possibility of danger from the wadding is guarded against'. ${ }^{63}$ All these findings, in consequence, led the Amherst embassy to believe that the Chinese were indeed a militarily weak nation.

The British observers' unfavourable perception of Chinese civilization was reinforced by their discoveries about the knowledge and characteristics of the Chinese people. As with 
the Macartney mission, members of Amherst's embassy were convinced by their experiences that the Chinese were indeed so ignorant that the Europeans 'can learn nothing from China'. ${ }^{64}$ Shortly after the embassy landed in China, Morrison realised that, although he had marked all the baggage in Chinese characters, the boatmen and porters were unable to read. ${ }^{65}$ Davis also noticed that the military mandarin attached to his boat could not even write in Chinese as well as he could and that this man's 'general ignorance on every subject ... made it vain to hope for any information from him'. ${ }^{66}$ When Abel, the naturalist, was collecting plants or examining stones during the journey, he was often laughed at by the natives and the escorting soldiers, as if he did so only to satisfy his peculiar curiosity. When Abel spoke to some of these people, he found the British to them were like 'inhabitants of another world', because 'our features, dress, and habits, were so opposed to theirs, as to induce them to infer that our country, in all its natural characters, must equally differ from their own. "Have you a moon, and rain, and rivers in your country?" were their occasional questions' ${ }^{67}$

Despite their profound ignorance, the British observers discovered that the Chinese still had a deep conviction of China's superiority over all other nations. In the vicinity of Shandong's northern frontier, the British envoys met the judge of Beizhili, a loquacious man who had a certain amount of knowledge about the world beyond China. Although he was 'better informed respecting the geography and history of European states, than any other Chinese with whom the Embassy became acquainted' ${ }^{68}$ this gentleman spoke of Britain as a country 'depending altogether on commerce ... great by sea, but weak by land' ${ }^{69} \mathrm{He}$ also asserted that, in contrast to the inferior position and status of Britain, 'the Chinese empire was in the center of the universe, and the supreme head of all nations'.${ }^{70}$ For this reason, due homage should by all means be paid by the British ambassador to the emperor of China in order to win concessions for British merchants who traded at Canton. Otherwise, the judge was afraid that 'it might prove the absolute ruin' ${ }^{71}$ of the British nation. To the British 
observers, this understanding of Britain as well as of Sino-British trade was so poor that 'ignorance and conceit were perhaps never more strongly combined'. ${ }^{72}$ Because of their unique sense of self-importance, the Chinese were found to be very reluctant to recognize anything foreign that appeared to be superior to their own designs. In terms of the different attitudes that the Chinese and the British adopted towards modern science and technology, Davis maintained that:

they are too proud to learn anything about us, while we foreigners of course never lose an opportunity of studying them in every relation of life, and have availed ourselves to some purpose of the opportunities, (scanty as these may have comparatively been,) which years of intercourse afforded us. That "power" which consists in "knowledge", therefore, preponderates on our side. ${ }^{73}$

Apart from their investigations into the Chinese people's knowledge, members of the Amherst embassy also attempted to examine the spiritual state and general character of the Chinese people. To begin with, it was discovered that, compared to the serious and exalted religious beliefs in Europe, religion in China 'has all the looseness and vanity with less of the solemnity and decency of ancient Polytheism'. ${ }^{74}$ According to the observations of these British travellers, there were no particular dates set aside for public worship, and nor did the Chinese attend temples congregationally. The majority of the Chinese population were utterly unselective in the deities to which they paid respect, so long as they believed that the practice would help avert mischief befalling them. Most of the priests in China were found to be uninstructed themselves, as well as largely illiterate. As mere performers of ceremonies, they neither preached like their counterparts did in Europe, nor were they treated by their followers with the reverence that was 'justly and reasonably due to the respectable ministers of religion in all countries' ${ }^{75}$ In view of these facts, Morrison claimed that: 
The general principles of our religion give a tone of elevation and dignity to the human mind which is not felt here. ... They do not associate under something approaching equality for the worship of their gods. ... The multitudes of people in this country are truly, in a moral and religious view, as 'sheep without a shepherd'. ${ }^{76}$

On the basis of such images, the main characteristics of the Chinese people were described as being 'selfish, cold-blooded and inhumane'. ${ }^{77}$ Morrison maintained that the professed moral maxims of the Chinese were actually 'ineffectual in regulating their minds and conduct'. ${ }^{78}$ Since the Chinese were never 'nice about a strict adherence to the truth', ${ }^{79}$ they could, in fact, be 'complaisant and servile, or insolent and domineering, according to circumstances' ${ }^{80}$ For instance, 'When interest or fear do not dictate a different course, they are to the strangers, haughty, insolent, fraudulent and inhospitable'. Moreover, 'A merchant will flatter a foreign devil (as they express it), when he has something to gain from him; then he can be servile enough; particularly if he is not seen by his own countrymen'. ${ }^{81}$ Abel, in this regard, pointed out that, particularly in the trading part of the Chinese community, 'the principle of cheating is so legitimated amongst them by the general practice and toleration of their countrymen, as to be considered rather as a necessary qualification to the successful practice of their calling, as an immoral quality' ${ }^{82}$ Because of what constantly occurred to the Amherst embassy, Abel added that, 'If giving false weight, charging centuple prices, and substituting bad articles for good, form a species of theft, it is not confined to the sea-coast, but is practised all over the empire of China, and is not only tolerated but applauded, especially when foreigners are its victims' ${ }^{83}$ Based on all these findings and experiences, when it came to the general character of the Chinese, Ellis contended that they were, 'half civilized, prejudiced' ${ }^{84}$ and 'without exaggeration', a 'nefarious' people. ${ }^{85}$ As for China's ranking in comparison to other civilizations in the world, Ellis concluded that, although it was 'superior to the other countries of Asia in the arts of government and the general aspects of society', China was undoubtedly 'inferior by many degrees to civilized Europe in all that 
constitutes the real greatness of a nation' ${ }^{86}$ On the question of whether the Chinese could justifiably be described as barbarians, Morrison produced the following statement:

If "barbarity" or being "barbarous" expresses something savage, rude and cruel, the present inhabitants of China do not deserve the epithet; if it expresses a cunning selfish policy, endeavouring to deceive, to intimidate, or to brow beat, as occasion may require, connected with an arrogant assumption of superiority on all occasions, instead of cultivating a liberal, candid, friendly intercourse with men of other nations, they are barbarians. ${ }^{87}$

These arguments put forward by Ellis and Morrison fairly represent the common opinions of the members of Amherst's embassy by the end of their visit to China. It can be clearly seen that the disagreements previously expressed on this subject had changed significantly. A consensus on the half-civilized image of China was reached by all the British observers who participated in the Amherst embassy and subsequently recorded their opinions on China and its people.

III

In seeking an explanation for the backwardness of Chinese civilization, members of the Amherst embassy concluded that the Qing government was the primary cause. Since, during the return journey, they were given many opportunities to visit Chinese cities and villages as well as to communicate with various different Chinese people, these British travellers were able to gather much more first-hand evidence than their predecessors on the real conditions in China. In particular, these observers were convinced that the suspicious government of China had deliberately designed its policies in order to suppress the natural sentiments and pursuits of its subjects. First of all, although the leading characteristics of the Chinese appeared to be prejudiced and inhuman, it was agreed that these qualities were more the consequence of the government's narrow policies than the natural disposition of the people. These observers 
maintained that the Qing government attached a great deal of importance to restricting contacts between foreigners and the Chinese people, and hence the country's foreign trade was restricted only to the port of Canton. Although the Macartney embassy had been permitted to pass through the interior of China, its members had not been allowed to make extensive contact with the local inhabitants. Because of such restrictions, the previous western impressions of the Chinese people and of the state of Chinese society were drawn mainly from evidence gained at Canton. This allowed Hall to admit that 'it is obviously as unfair to judge of the Chinese by such data, as it would be to estimate the character of the English from such materials as Rotherhithe and Wapping might afford' ${ }^{88}$

Over recent centuries, in those regions, such as Canton, where frequent engagements with foreign people had taken place, ${ }^{89}$ or amongst those social classes whose professions and activities involved contact with foreigners, a belief in the inferiority of all foreign nations and a distrust of their good intentions had been promoted by the Qing authorities. In consequence, a deep prejudice against as well as a serious contempt for all foreigners had been inculcated in the minds of the Chinese people. Despite this, members of the Amherst embassy found that, 'in places remote from Canton, and where it is not the policy of the local authorities to discourage all inquiry, there is no jealousy or apprehension of strangers' ${ }^{90}$ When they travelled to some places which had 'probably never before been visited by any Europeans', ${ }^{91}$ these British visitors often discerned and benefited from the cheerful disposition and hospitality of the local inhabitants. This claim can be supported by many examples found in the accounts produced by members of the Amherst mission. For example, Clarke Able noted that:

I was often enabled to get amongst them apart from my friends and usual attendant soldiers, and always found them mild, forbearing, and humane. ${ }^{92} \ldots$ especially when they were peasants, [they] afforded a pleasing contrast in their simple manners and civil treatment of strangers, to the cunning designs of the 
salesmen of Tung-Chow, and the brutal importunity of the courtiers of YuenMing-Yuen. ${ }^{93}$

Ellis added that, when he entered the dwellings of some local residents, 'No dislike is shewn by the people in general to natural inquisitiveness; on the contrary, our momentary intrusions have been met by invitations to sit down' ${ }^{94}$ In contrast with the prevailing impression that the Chinese were guarded in their relations with foreigners, these friendly natives either pressed them to partake of their meals or supplied them with tea, or even invited these visiting strangers to examine the yards and outer apartments of their houses. ${ }^{95}$ As a result of these experiences, members of the Amherst mission were further persuaded that it was the deliberate policies of the Qing government that considerably altered the genuine disposition of the Chinese people.

In addition to its efforts to restrict the nation's contact with foreign peoples, the Chinese government was also found to be promoting tensions and difficulties within the country's hierarchical society. On the one hand, the Chinese people was placed in awe of the government, because, under the powerful hand of that authority, government officials 'have the knack of rendering life very miserable, and assume the power of bambooing, torturing, fining (or squeezing), and every species of oppression short of death'.${ }^{96}$ Throughout their journey, the British travellers witnessed a number of cases where Chinese men and women were bambooed or face-slapped after making trifling mistakes. Some poor people were also seen to be forced by the embassy's attendant officials to work without charge for the fleet. ${ }^{97}$ As a result of these facts, it was believed that, 'China does not enjoy liberty. Her government is a military despotism. ... The strong arm of power intimidates them' ${ }^{98}$ In consequence, the Chinese people were seriously discouraged from discussing affairs of state or forming any societies which might seek to influence or oppose the government. Moreover, since according to the criminal code of China, 'an ineffectual attempt to save the life of another, under the 
slightest shade of suspicion, is followed by the punishment of death', ${ }^{99}$ the Chinese were found unwilling to give assistance even if they saw someone's life was in danger. Instead of taking this as an example of the Chinese people's inhumane character, however, the British observers attributed it to the 'absurd and unjust principles upon which the Chinese laws are administered by the mandarins'. ${ }^{100}$ John Macleod, for example, clearly stated that, 'It is lamentable to observe that the institutions of any nation should have the effect of deadening every feeling of sympathy, and of exciting, instead of discouraging, "man's inhumanity to man;" but such is the case in this country'. ${ }^{101}$

On the other hand, it was agreed by these British observers that the mandarins themselves were also not free from concerns about their own self-preservation. Their offices and lives were totally subject to the will of the Chinese emperor, insomuch that "not only the more important measures of government, but the most trifling details of office, depend for their execution upon the supposed irresistibility of the imperial power' ${ }^{102}$ In particular, these British visitors were informed that 'in the event of any suspicion of a collusion with foreigners', the emperor's 'single word was sufficient to consign them [the mandarins] to death' ${ }^{103}$ For the members of the Amherst embassy this explained the sharp contrast between the attendant officers' extremely reserved manner in the vicinity of Beijing and the good temper they manifested during the rest of their time with the embassy. In the early stages of the return journey, Amherst believed that, 'Being now at so short a distance from the Capital, it appeared probable that most questions would be decided by an immediate appeal to the Emperor himself' ${ }^{104}$ Probably for this reason, the mandarins appeared quite cautious about entering into any formal conversation with the British envoys and nothing could induce them to accept any presents. Nevertheless, it was observed that 'as we receded from the neighbourhood of Peking, the mandarins had become more frequent and less reserved in their visits, very readily accepting any presents that were made them'. ${ }^{105}$ In light of these 
discoveries, the British observers were led to believe that, just as with the Chinese populace, the government officials in China were entirely at the mercy of their sovereign. Their liberty and natural sentiments were therefore greatly restricted and constrained by the power and caution of the Chinese emperor.

Last, but not least, the government of China was viewed by the Amherst embassy as the chief obstacle to the Chinese people's pursuit of knowledge and wellbeing, as well as to the progress of Chinese civilization. To justify this conclusion, Macleod maintained that, the Chinese government not only made its people believe 'themselves at the summit of perfection', but established 'the absurd tyranny of fettering the human understanding, by forbidding all innovation and improvement' ${ }^{106}$ For instance, although some Chinese people did indeed have an interest in astronomy, the study of the human frame, western medical practices, and so on, ${ }^{107}$ the Chinese government prohibited the masses from undertaking such studies. Instead, it narrowed their ideas 'by compelling their attention, and attaching importance, entirely to the observance of useless forms and ceremonies', ${ }^{108}$ and 'by admitting of no deviation from one contracted path, even in the simplest transactions of life'. ${ }^{109}$ In particular, Davis maintained that the Chinese government 'habitually inculcate[d] $a$ respectful demeanour on the part of young people towards their elders'. ${ }^{110}$ The benefits of such institutions were considered to be so apparent in their effects, because 'in no country of the world does a quiet, easy subordination so extensively prevail as in China', where the 'inexperience and headstrong passion of youth' were repressed without inspiring resistance. ${ }^{111}$ Furthermore, these British commentators contended that many measures adopted by the Chinese government were inimical to the welfare of the people and also restricted the development of China's civilization. For example, during their travel through the Chinese interior, members of the Amherst embassy discovered that, although China's foreign trade was restricted to Canton, there was actually much interest and eagerness on the 
part of the Chinese people to trade with the British. ${ }^{112}$ Moreover, in those places where greater engagement with westerners took place, particularly in Canton, the British travellers claimed that they were able to discern a distinct air of opulence that was hard to see in the rest of China. Ellis noted in this regard that:

\begin{abstract}
Canton, from the number and size of the vessels, the variety and decorations of the boats, the superior architecture of the European factories, and the general buzz and diffusion of a busy population, had, on approaching, a more imposing appearance than any Chinese city visited by the present embassy; nor do I believe, that in the wealth of the inhabitants at large, the skill of the artificers, and the variety of the manufactures, it yields, with the exception of the capital, to any city in the empire. ... The whole effect of foreign commerce is here concentrated and displayed, and the employment which the European trade affords to all classes of the inhabitants diffuses an air of general prosperity, not to be expected where this powerful stimulus does not operate. ${ }^{113}$
\end{abstract}

With regard to this phenomenon, these British travellers were convinced that it was 'owing greatly to hints furnished by our examples' ${ }^{114}$ rather than being due to any positive influence exerted by the local government. To prove this, evidence was provided to demonstrate that the communities around Canton had benefited remarkably from modern technology introduced by the British. Abel noted in his narrative that:

The small pox, which for centuries has at different periods made dreadful havock all over the empire, is likely soon to be extirpated by the benign influence of vaccination establishing under the auspices of Mr Pierson the principal surgeon of the British factory. ... Native vaccinators have been appointed and educated under the eye of Mr Pierson, and are taking from him the labour of inoculating the lowest class of Chinese. I witnessed their operations in a temple near the British factory, on some of the children of the hundreds of anxious parents who flocked to procure the preservation of their offspring from the small pox, at that time prevalent at Canton. If the paternal government of China can free itself from national prejudices, it will erect a monument of gratitude to the discovery of Jenner, and the services of Pierson. ${ }^{115}$

In contrast to such positive benefits arising from contact with a more advanced civilization, the British observers lamented that similar changes had been rendered impossible in the rest 
of the Chinese empire because of the policies deliberately adopted by the Qing government. For this reason, the common belief within the embassy was further strengthened that the Chinese 'have had for some thousand years a dawn of civilization', but, 'from the operation of the most narrow-minded principles', it 'has never brightened into day'. ${ }^{116}$ Accordingly, the suspicious Qing government, as the designer of such restrictive policies, was seen to be the primary cause of China's backwardness and the country's stagnant civilization.

The unprecedented freedom of movement afforded the members of the Amherst embassy during their return journey through China allowed these British observers to explore the interior of China and to communicate more fully with the Chinese government and people than ever before. As a result of the considerable first-hand evidence gathered and subsequently published by these men, a consensus was reached about the backward image of China and some unfavourable perceptions of Chinese civilization, which had already been circulating in Britain, were rendered more credible than ever before. To explain China's backwardness, the Qing government was blamed by these British visitors as being chiefly responsible for placing obstacles in the way of the progress of Chinese civilization as well as damaging the general welfare of the Chinese people. This view of the Qing government, to a great extent, laid the foundations for the mounting hostile attitude in Britain towards the government of China in the following decades. By 1840, many in Britain had come to the conclusion that the unreliable government of China not only constrained the Chinese people's pursuit of personal and commercial freedom, but was beginning to endanger Britain's commercial interests and national honour in Asia. This made it easier to justify a policy of open hostility towards China that came to be accepted by a majority in the British parliament. Although it cannot be maintained that the unfavourable impressions of China and the Qing government conveyed to the public by the published accounts of members of the Amherst embassy had determined the outbreak of the Opium War, open conflict with China would 
probably not have been as imaginable or as acceptable without the evidence provided by these members of the Amherst mission. The British, moreover, probably would not have been confident enough to attack such a large and populous country as China had they not become convinced of China's serious decay and growing weakness. For these reasons, the Amherst embassy should not be regarded simply as a diplomatic failure. Its significance in the history of British-Chinese relations is much more profound than it appears to be if we look closely only at Amherst's failure to meet the Chinese emperor because of his refusal to kowtow to his imperial majesty.

${ }^{1}$ For example, Hosea Ballou Morse, The Chronicles of the East India Company Trading to China, 1635-1834 (5 vols., Oxford, 1926), III, 256-306; Alain Peyrefitte, The Collision of Two Civilisations: The British Expedition to China in 1792-4 (London, 1993), pp. 504-11; Christopher Hibbert, The Dragon Wakes: China and the West, 1793-1911 (New York, 1984), pp. 54-69; A.E. Grantham, A Manchu Monarch: an interpretation of Chia Ching (Arlington, VA, 1976), 154-201; and Li Chien-nung, The Political History of China, 1840-1928 (Princeton, NJ, 1956) [hereafter Li, The Political History of China], pp. 17-18.

${ }^{2}$ Li, The Political History of China, p. 18.

${ }^{3}$ The Qing court ritual required foreign envoys to pay sangui jiukou before the Chinese emperor. This utmost form of ceremonial observance, commonly known as 'kowtow', required thrice kneeling and nine times bowing the head to the ground. Both Macartney and Amherst refused to perform this ceremony, because they regarded it as a gross insult to the British sovereign. See Eun Kyung Min, 'Narrating the Far East: commercial civility and ceremony in the Amherst Embassy to China (1816-1817)', in B.R. Wells and P. Steward (eds.), Interpreting Colonialism (Oxford, 2004), pp. 160-80; Wu Xiaojun 吴晓钧, 
‘A'meishide shijietuan tanxi: yi tianchao guan zhi shijian wei zhongxin' 阿美士德使节团探 析: 以天朝观之实践为中心 ('On the Amherst mission: with its focus on the practice of the world view of the celestial empire'), unpublished MA dissertation (National Tsing Hua University, 2008). There are many studies of the kowtow controversy during the Macartney embassy. See James L. Hevia, Cherishing men from afar: Qing guest ritual and the Macartney Embassy of 1793 (Durham, NC, 1995); Robert Bickers (ed.), Ritual and Diplomacy: The Macartney mission to China, 1792-1794 (London, 1993); Huang Yinong 黄 一农, 'Yinxiang yu zhenxiang: qingchao zhongying liangguo de guanli zhizheng' 印象与真 相：清朝中英两国的观礼之争 ('Impressions vs. Reality: a study on the guest ritual controversy between Qing China and Britain'), Zhongyang yanjiuyuan lishi yuyan yanjiusuo jikan 中央研究院历史研究所集刊 (Bulletin of the Institute of History and Philology Academia Sinica), 78/1 (2007), 35-106.

${ }^{4}$ There are a number of secondary sources which have examined Europe's early views of China. These include: P.J. Marshall and Glyndwr Williams, The Great Map of Mankind: Perceptions of New Worlds in the Age of Enlightenment (Cambridge, MA, 1982) [hereafter Marshall and Williams, The Great Map of Mankind]; Colin Mackerras, Western Images of China (Oxford, 1989); V.G. Kiernan, The Lords of Human Kind: European attitudes towards the outside world in the imperial age (London, 1995); Jonathan D. Spence, The Chan's Great Continent: China in the Western Minds (London, 2000); and Gregory Blue, 'China in western social thought: with special reference to contributions from Montesquieu to Max Weber', unpublished $\mathrm{PhD}$ dissertation (University of Cambridge, 1989).

${ }^{5}$ For example, Sir William Temple (1628-99), Britain's most famous sinophile in the seventeenth century, wrote very highly of the Chinese form of government and the philosophy of Confucius. See William Temple, The Works of Sir William Temple (4 vols., 
London, 1770; reprinted, New York, 1968), III, 325-45, 455-8. Britain's enthusiasm for China generally began to decline after the death of Temple.

${ }^{6}$ Chong-kun Yoon, 'Sinophilism during the Age of Enlightenment: Jesuits, Philosophes and Physiocrats discover Confucius', in Henry A. Myers (ed.), Western Views of China and the Far East (2 vols., Hong Kong 1982), I, 174-5.

${ }^{7}$ Marshall and Williams, The Great Map of Mankind, p. 175.

${ }^{8}$ George Anson, A Voyage Round the World in the Years 1740-1744 (London, 1748). Anson reached China in 1743, but only skirted the coast of Canton. Despite his short stay, Anson formed very critical views of the Chinese people and their government.

${ }^{9}$ J.L. Cranmer-Byng (ed.), An Embassy to China: Being the journal kept by Lord Macartney during his embassy to the Emperor Ch'ien-lung 1793-1794 (London, 1962) [hereafter An Embassy to China], p. 222; and George L. Staunton, An Authentic Account of an Embassy from the King of Great Britain to the Emperor of China (2 vols., London, 1798), II, 514. Similar views can also be found in John Barrow, Travels in China (Philadelphia, PA, 1805), p. 238.

${ }^{10}$ An Embassy to China, p. 87.

${ }^{11}$ Ibid., p. 88.

${ }^{12}$ British Library, London: India Office Library and Records [hereafter IOLR]: India Office Amherst Correspondence, Lord Amherst's Embassy, 1815-17, vols. 197, G/12/197/281. Letter from Amherst to George Canning, 8 March 1817.

${ }^{13}$ John Francis Davis, Sketches of China; Partly during an Inland Journey of Four Months between Peking, Nanking, and Canton (2 vols., London, 1841) [hereafter Davis, Sketches of China], II, 29.

${ }^{14}$ These works include: George T. Staunton, Notes of Proceedings and Occurrences during the British Embassy to Pekin in 1816 (London, 1824) [hereafter Staunton, Notes of 
Proceedings]; George T. Staunton, Miscellaneous Notices Relating to China, and our Commercial Intercourse with that Country (London, 1822) [hereafter Staunton, Miscellaneous Notices]; and George T. Staunton, Memoirs of the Chief Incidents of the Public Life of Sir George T. Staunton (London, 1856).

${ }^{15}$ Henry Ellis, Journal of the Proceedings of the late Embassy to China (London, 1817) [hereafter Ellis, Journal of the Proceedings].

${ }^{16}$ Robert Morrison, A View of China, for philological purposes: containing a sketch of Chinese chronology, geography, government, religion and customs (London, 1817) [hereafter Morrison, A View of China].

${ }^{17}$ Robert Morrison, A Memoir of the Principal Occurrences during an Embassy from the British Government to the Court of China in the year 1816 (London, 1820) [hereafter Morrison, A Memoir].

${ }^{18}$ Eliza Morrison (ed.), Memoirs of the Life and Labours of Robert Morrison, D.D. (2 vols., London, 1839) [hereafter Memoirs of Robert Morrison].

${ }^{19}$ In 1813, Davis was appointed writer in the East India Company’s factory at Canton. After that his career was closely associated with Chinese affairs. Davis later served as the Governor of Hong Kong from 1844 to 1848.

${ }^{20}$ Clarke Abel, Narrative of a Journey in the Interior of China in the years 1816-1817 (London, 1818) [hereafter Abel, Narrative of a Journey]; John Macleod, Narrative of a Voyage in His Majesty's Late Ship Alceste to the Yellow Sea, along the Coast of Corea, and through its numerous hitherto undiscovered islands, to the island of Lewchew (London, 1817) [hereafter Macleod, Narrative of a Voyage]; Basil Hall, Narrative of a Voyage to Java, China and the great Loo-Choo Island (London, 1840) [hereafter Hall, Narrative of a Voyage]; and Adam Matthew Microform Publications: Henry Hayne, Henry Hayne Dairy 1816-1817 (4 
vols.), China through western eyes: manuscript records of traders, travellers, missionaries and diplomats, 1792-1942 (London, 1996).

${ }^{21}$ Edward W. Said, Orientalism (London, 1995), pp. 1-28.

${ }^{22}$ Elizabeth Hope Chang, Britain's Chinese Eye: Literature, Empire and Aesthetics in Nineteenth-Century Britain (Stanford, CA, 2010), p. 22.

23 An Embassy to China, p. 212.

${ }^{24}$ See Susan M. Jones and Philip A. Kuhn, 'Dynastic decline and the roots of rebellion', in John K. Fairbank, et al. (eds.), The Cambridge History of China (15 vols., Cambridge, 1978), X, 107-62; and Wei Kewei 魏克威, 'Lun Jiaqing zhongshuai de yuanyin' 论嘉庆中衰的原 因 ('On the reasons for the Qing dynasty’s decline during the Jiaqing reign'), Qingshi yanjiu, 2 (1992), 39-44.

${ }^{25}$ Staunton, Notes of Proceedings, p. 157.

${ }^{26}$ Ibid., p. 205. It is now common knowledge among historians that the decline of Qing dynasty indeed commenced in the late Qianlong (1735-95) and Jiaqing (1796-1820) reigns. See Philip A. Kuhn, Origins of the Modern Chinese State (Stanford, CA, 2002), pp. 2-8.

${ }^{27}$ Staunton, Notes of Proceedings, p. 69.

${ }^{28}$ Staunton had a good command of the Chinese language. The Peking Gazette was a staterun bulletin in which acknowledgements of and allusions to the emperor's fiscal condition could be found. See Staunton, Notes of Proceedings, p. 69.

${ }^{29}$ Ibid., p. 157.

${ }^{30}$ Ibid., p. 380.

${ }^{31}$ Ibid., pp. 435-7.

${ }^{32}$ Ellis, Journal of the Proceedings, p. 218.

${ }^{33}$ Ibid., p. 364.

${ }^{34}$ Davis, Sketches of China, II, 2-3. 
${ }^{35}$ Abel, Narrative of a Journey, p. 11.

${ }^{36}$ Ellis, Journal of the Proceedings, p. 197.

${ }^{37}$ Morrison, A Memoir, p. 8.

${ }^{38}$ Ibid., p. 9.

${ }^{39}$ Hall, Narrative of a Voyage, p. 8.

${ }^{40}$ Abel, Narrative of a Journey, p. 87.

${ }^{41}$ Ibid.

${ }^{42}$ Ibid., pp. 75, 128.

${ }^{43}$ Ibid., p. 230.

${ }^{44}$ Ibid., p. 232.

${ }^{45}$ Ellis, Journal of the Proceedings, p. 205.

${ }^{46}$ Ibid., p. 301.

${ }^{47}$ Abel, Narrative of a Journey, p. 159.

${ }^{48}$ Ellis, Journal of the Proceedings, p. 157.

${ }^{49}$ Morrison, A Memoir, pp. 31-2.

${ }^{50}$ Davis, Sketches of China, I, 144. Italics in the original. Emperors Yao and Shun are semimythological rulers in ancient Chinese history.

${ }^{51}$ Abel, Narrative of a Journey, p. 153.

${ }^{52}$ Davis, Sketches of China, I, 249.

${ }^{53}$ Staunton, Notes of Proceedings, p. 143.

${ }^{54}$ Abel, Narrative of a Journey, p. 71.

${ }^{55}$ Ibid., p. 94.

${ }^{56}$ Morrison, A Memoir, p. 38.

${ }^{57}$ Davis, Sketches of China, I, 148-9.

${ }^{58}$ Morrison, A Memoir, p. 38. 
${ }^{59}$ Davis, Sketches of China, I, 248.

${ }^{60}$ Ellis, Journal of the Proceedings, p. 253.

${ }^{61}$ Davis, Sketches of China, I, 90.

${ }^{62}$ Ibid., 91.

${ }^{63}$ Ellis, Journal of the Proceedings, p. 202.

${ }^{64}$ Morrison, A View of China, p. 121.

${ }^{65}$ Morrison, A Memoir, p. 13.

${ }^{66}$ Davis, Sketches of China, I, 186.

${ }^{67}$ Abel, Narrative of a Journey, p. 141.

${ }^{68}$ Ibid., p. 144.

${ }^{69}$ Staunton, Notes of Proceedings, p. 141.

${ }^{70}$ Ibid., p. 163.

${ }^{71}$ Ibid., p. 162.

${ }^{72}$ Davis, Sketches of China, I, 179.

${ }^{73}$ Ibid., 109.

${ }^{74}$ Ellis, Journal of the Proceedings, p. 438.

${ }^{75}$ Macleod, Narrative of a Voyage, p. 151.

${ }^{76}$ Memoirs of Robert Morrison, I, 447-8.

${ }^{77}$ Morrison, A View of China, p. 125.

${ }^{78}$ Ibid., p. 122.

${ }^{79}$ Ibid.

${ }^{80}$ Morrison, A Memoir, p. 67.

${ }^{81}$ Morrison, A View of China, p. 125.

${ }^{82}$ Abel, Narrative of a Journey, p. 232.

${ }^{83}$ Ibid., p. 113. 
${ }^{84}$ Ellis, Journal of the Proceedings, p. 388.

${ }^{85}$ Ibid., p. 384.

${ }^{86}$ Ibid., p. 429.

${ }^{87}$ Morrison, A Memoir, p. 67.

${ }^{88}$ Hall, Narrative of a Voyage, p. 10.

${ }^{89}$ Prior to 1757, China's external trade was open to three more ports: Ningbo, Quanzhou and Songjiang.

${ }^{90}$ Hall, Narrative of a Voyage, p. 14.

${ }^{91}$ Ibid., p. 10.

92 Abel, Narrative of a Journey, p. 232.

${ }^{93}$ Ibid., p. 130.

${ }^{94}$ Ellis, Journal of the Proceedings, pp. 163-4.

${ }^{95}$ Abel, Narrative of a Journey, pp. 119-20; Ellis, Journal of the Proceedings, pp. 164, 283; and Hall, Narrative of a Voyage, pp. 10, 12, 14, etc.

${ }^{96}$ Macleod, Narrative of a Voyage, p. 153.

${ }^{97}$ Examples can be found in Abel, Narrative of a Journey, p. 138; Morrison, A Memoir, pp. 16, 60-2; Davis, Sketches of China, I, 193, 292; and Macleod, Narrative of a Voyage, p. 153, etc.

${ }^{98}$ Morrison, A Memoir, p. 67. Italics in the original.

${ }^{99}$ Abel, Narrative of a Journey, p. 236.

${ }^{100}$ Staunton, Notes of Proceedings, p. 182.

${ }^{101}$ Macleod, Narrative of a Voyage, p. 156.

102 Ellis, Journal of the Proceedings, p. 241.

${ }^{103}$ Davis, Sketches of China, I, 168.

${ }^{104}$ IOLR, G/12/197/256-7. Letter from Amherst to George Canning, 28 February 1817. 
${ }^{105}$ Davis, Sketches of China, I, 248-9. See also Ellis, Journal of the Proceedings, p. 247; IOLR, G/12/197/317-8. Letter from Amherst to George Canning, 22 March 1817.

${ }^{106}$ Macleod, Narrative of a Voyage, p. 159.

${ }^{107}$ Examples can be found in Abel, Narrative of a Journey, pp. 216-17.

${ }^{108}$ Macleod, Narrative of a Voyage, p. 160. In this respect, the British travellers were informed that even the Chinese emperor was subject to various forms of court ritual, so that in some ways the monarch himself was also 'a slave to ceremony'. See Davis, Sketches of China, II, 23.

${ }^{109}$ Macleod, Narrative of a Voyage, p. 160.

${ }^{110}$ Davis, Sketches of China, I, 38. Italics in the original.

111 Ibid.

${ }^{112}$ Examples can be found in Staunton, Notes of Proceedings, p. 40; Ellis, Journal of the Proceedings, p. 14; Abel, Narrative of a Journey, p. 6, etc.

${ }^{113}$ Ellis, Journal of the Proceedings, p. 408. Ellis also suggested herein that 'The traveller who only sees Canton will be liable to form an exaggerated opinion of the population and wealth of China'.

${ }^{114}$ Davis, Sketches of China, II, 149.

${ }^{115}$ Abel, Narrative of a Journey, pp. 218-19.

${ }^{116}$ Macleod, Narrative of a Voyage, p. 158. 